\title{
The Responsibility to Protect and the Question of Attribution
}

DOI:

10.1080/14781158.2018.1430026

\section{Document Version}

Accepted author manuscript

Link to publication record in Manchester Research Explorer

\section{Citation for published version (APA):}

Aistrope, T., Gifkins, J., \& Taylor, N. A. J. (2018). The Responsibility to Protect and the Question of Attribution. Global Change, Peace and Security, 30(1). https://doi.org/10.1080/14781158.2018.1430026

\section{Published in:}

Global Change, Peace and Security

\section{Citing this paper}

Please note that where the full-text provided on Manchester Research Explorer is the Author Accepted Manuscript or Proof version this may differ from the final Published version. If citing, it is advised that you check and use the publisher's definitive version.

\section{General rights}

Copyright and moral rights for the publications made accessible in the Research Explorer are retained by the authors and/or other copyright owners and it is a condition of accessing publications that users recognise and abide by the legal requirements associated with these rights.

\section{Takedown policy}

If you believe that this document breaches copyright please refer to the University of Manchester's Takedown Procedures [http://man.ac.uk/04Y6Bo] or contact uml.scholarlycommunications@manchester.ac.uk providing relevant details, so we can investigate your claim.

\section{OPEN ACCESS}




\title{
The Responsibility to Protect and the Question of Attribution
}

\author{
Tim Aistrope, Jess Gifkins and N.A.J. Taylor
}

\begin{abstract}
This article explores the problem of attribution in the context of R2P intervention through an analysis of the Syrian chemical weapons attack of 2013. We argue that R2P advocates can be confronted by a crisis dynamic where the political momentum for military intervention runs ahead of independent verification and attribution of mass atrocity crimes. We contrast the political momentum for intervention with the technical process of independent attribution and show that the sort of independent evidence that would ideally legitimize an R2P intervention was unavailable when there was political momentum for action. Conversely, the information that was available (which inevitably informed the political momentum for action) was largely produced by state intelligence organisations - or a potentially briefed media - and shaped by the interests and priorities of its end users. While understandable in the face of the 'extreme', we suggest that the mobilisation of political momentum by R2P advocates entails significant dangers: first, it risks undermining the integrity of R2P if evidence is later discredited; and, second, it risks amplifying the perception that states sometimes exploit humanitarian pretexts in pursuit of other strategic ends.
\end{abstract}

\section{Introduction}

The Responsibility to Protect (R2P) has been a prominent and sometimes controversial feature of both academic and policy-oriented debates for more than a decade. At times it has seemed as if encounters between R2P advocates and critics have generated more heat than light and that their differences are more irreconcilable than ever. This is no doubt because both advocates and critics are motivated by a genuine attempt to prevent extreme violence directed towards civilians. On the one side, R2P advocates are compelled by the horrific circumstances of mass atrocity crimes, such as those that occurred in Rwanda and Srebrenica, as well as more recently in Libya and Syria. On the other side, critics are compelled by a concern that the idea of R2P might be exploited by states as a pretext for politico-strategic objectives, which can escalate, sustain or give rise to further violence. In other words, 
the debate largely concerns how best to reconcile the normative and political content of R2P.

In this article, we attempt to draw a line through this debate by closely examining the discourse that surrounded the Syrian chemical weapons attacks of $2013 .{ }^{1}$ This is a particularly useful case for three reasons. First, the issue of chemical weapons explicitly draws security and humanitarian imperatives into the same discursive space-a dynamic captured in the International Relations (IR) literature on the 'chemical weapons taboo'. ${ }^{2}$ Second, the framing of chemical weapons as Weapons of Mass Destruction (WMD) has served to politicise both their actual and potential use, particularly since the 2003 Iraq War. Third, the attribution of the chemical weapons attack was contested in ways that reflected the geopolitical structure of the Syrian conflict. Together, these dynamics make this a useful case for investigating the intersection of political and normative imperatives around $\mathrm{R} 2 \mathrm{P} .{ }^{3}$

We argue that $\mathrm{R} 2 \mathrm{P}$ advocates can be confronted by a crisis dynamic where the political momentum for military intervention runs ahead of independent verification and attribution of mass atrocity crimes. We analyse the political discourse after the Syrian chemical weapons attack and highlight the way many advocates called for R2P

\footnotetext{
${ }^{1}$ This collaboration was born out of a desire for dialogue on humanitarian intervention that reaches across subdisciplinary boundaries — in this case, security/IR theory (Tim Aistrope), R2P/UN (Jess Gifkins), and arms control and disarmament (N.A.J. Taylor). For an earlier discussion of the Syrian crisis that sparked this conversation, see Taylor, N.A.J. (2013), 'Responsibly protecting Syrians', Iraq War Inquiry Group, May 13, 2013, accessed at http://iraqwarinquiry.blogspot.com.au/2013/08/responsibly-protecting-syrians.html on August 2013; and Tim Aistrope, Jess Gifkins and N.A.J. Taylor, 'Responsibly protecting Syrians: Reconciling R2P with the Chemical Weapons Taboo', Oceanic Conference on International Studies, University of Queensland, July 5, 2016. Throughout this process we received generous feedback that improved the article significantly. In particular, we would like to thank the two anonymous reviewers, as well as Tony Burke, Deane-Peter Baker, Peter Balint, Toni Erskine, Luke Glanville, Anna Tanascosa, Sarah Teitt, and Ramesh Thakur. We are also very grateful to the International Ethics Research Group hosted by UNSW Canberra to which an earlier version of the article was presented.

${ }^{2}$ Richard Price, 'A Genealogy of the Chemical Weapons Taboo', International Organization, 49, no. 1 (1995): 73-73; Richard Price, The Chemical Weapons Taboo. (Ithaca: Cornell University Press, 1997); Richard Price, 'No Strike, No Problem'. Foreign Affairs, September 5, https://www.foreignaffairs.com/articles/syria/2013-09-05/nostrike-no-problem (2013); Richard Price, 'How Chemical Weapons Became Taboo', Foreign Affairs, December 16, https://www.foreignaffairs.com/articles/syria/2013-01-22/how-chemical-weapons-became-taboo (2015).

${ }^{3}$ The article also contributes to critical engagements with the role of security intelligence and WMD politics underway at the Harvard Sussex Program. For discussion, see Julian Perry Robinson, 'Alleged Chemical Weapons Use in Syria', Issue 4, Occasional Paper Series, (Harvard Sussex Program, 2013); Caitriona McLeish, James Revill, and Julian Philip Perry Robinson, 'Some Potential Implications for the Chemical Weapons Regime Resulting from the Syria Case', Reports and working papers, (Harvard Sussex Program, 2016), http://srodev.sussex.ac.uk/61837/ (2016); James Revill, Alex Ghionis, Caitriona McLeish, and Steve Johnson, 'Ghouta Narratives: A Critical Assessment of Syrian Chemical Weapons Narratives', Reports and working papers, (Harvard Sussex Program, 2016) http://sro.sussex.ac.uk/61840/. Other critical engagements that are no less useful but with less direct applicability to the present inquiry are available in related programs in the U.K. (e.g. at Bath, Bradford, Kings College London), and in Belgium.
} 
intervention, with the proviso that the role of the Syrian government was proven. We then contrast the momentum for intervention with the technical process of independent attribution carried out by the United Nations (UN) Organisation for the Prohibition of Chemical Weapons (OPCW). We show that the sort of independent evidence that would ideally legitimize an $\mathrm{R} 2 \mathrm{P}$ intervention was unavailable when there was political momentum for action. Conversely, the information that was available (which inevitably informed the political momentum for action) was largely produced by state intelligence organisations - or a potentially briefed media - and shaped by the interests and priorities of its end users. While understandable in the face of the 'extreme', we suggest that the mobilisation of political momentum by R2P advocates entails significant dangers: first, it risks undermining the integrity of R2P if evidence is later discredited; and, second, it risks amplifying the perception that states sometimes exploit humanitarian pretexts in pursuit of other strategic ends.

In order to make this case, the first section begins by outlining the various claims made about the Syrian chemical weapons incident of 2013. The second section explores the dangers of mobilising political momentum by examining the reliability of evidence provided by states to make the case for military interventions. We do this via an analysis of 'intelligence', which is an information product that makes probabilistic estimates about current events and possible futures. We then show that crisis dynamics can incentivise information emanating from states over and above independent attribution. Section three assesses the significance of these insights for the $\mathrm{R} 2 \mathrm{P}$ project and identifies some practices that are particularly vulnerable to these crisis dynamics.

However, before we proceed we must first establish the scope of this article, which includes what we mean by 'R2P'. Our understanding of R2P draws from the version that was agreed by national leaders in the 2005 World Summit outcome document. Here they were clear that R2P is concerned with four mass atrocity crimes: genocide, war crimes, ethnic cleansing and crimes against humanity. ${ }^{4}$ As such, former UN Secretary-General Ban Ki-moon described it as 'narrow but deep'. ${ }^{5}$ What this means is that $\mathrm{R} 2 \mathrm{P}$ is not synonymous with humanitarian intervention, but encompasses

\footnotetext{
${ }^{4}$ United Nations, World Summit outcome document, (United Nations General Assembly, A/RES/60/1, 2005).

5 Ban Ki-moon, 'Secretary-General Defends, Clarifies 'Responsibility to Protect'" at event on 'Responsible Sovereignty: International Cooperation for a Changed World', Available at http://www.un.org/News/Press/docs/2008/sgsm11701.doc.htm (Berlin, 2008).
} 
questions as wide-ranging as inclusive governance and strengthening domestic resilience, which can be effective in militating against such crimes. ${ }^{6}$ This article discusses the coercive (and contentious) elements of R2P, but we start from the understanding that this is only one aspect of what R2P involves.

It can be helpful then to conceptualise $\mathrm{R} 2 \mathrm{P}$ as three pillars - a frame used by the United Nations and by most R2P literature currently. The first pillar requires states to protect their own populations from mass atrocity crimes, and applies to all states always. The second pillar envisages a cooperative relationship between states and relevant neighbours, regional organisations and international organisations, whereby states are assisted in providing protection to their peoples. ${ }^{7}$ Pillar three can involve consensual tools ${ }^{8}$ such as mediation, peacebuilding and unarmed civilian peacekeeping ${ }^{9}$, as well as coercive tools such as sanctions and peace enforcement where states have 'manifestly failed' to provide such protection. Unsurprisingly, pillars one and two are less contentious as they presume only consensual actions. We understand $\mathrm{R} 2 \mathrm{P}$ as a spectrum of activities and tools, aimed at preventing and responding to mass atrocity crimes, which can include both consensual and coercive elements. R2P does not equate to humanitarian intervention, despite some who argue that the primary focus of R2P is or should be humanitarian intervention, ${ }^{10}$ and others who fear that R2P will lead to more use of humanitarian intervention. ${ }^{11}$

Given the many concerns of R2P, we deploy a further delineation in the final section of the essay: 'policy agenda' and 'rallying cry'. ${ }^{12}$ The 'policy agenda' heading refers to the ideal that effective use of prevention tools will lead to fewer crisis situations

\footnotetext{
${ }^{6}$ Stephen McLoughlin, The Structural Prevention of Mass Atrocities: Understanding Risk and Resilience (Abingdon: Routledge, 2014).

${ }^{7}$ For discussion on pillar two, see Adrian Gallagher, (2015). 'The Promise of Pillar II: Analysing international assistance under the Responsibility to Protect', International Affairs, 91, no. 6: 1259-1275.

${ }^{8}$ For discussion on the peaceful components of pillar three, see Alex J. Bellamy, 'The First Response: Peaceful means in the third pillar of the Responsibility to Protect', (Stanley Foundation Policy Analysis, December, 2015).

${ }^{9}$ For discussion on unarmed civilian peacekeeping see Ellen Furnari, Huibert Oldenhuis and Rachel Julian, 'Securing Space for Local Peacebuilding: The Role of International and National Civilian Peacekeepers', Peacebuilding, 3 no. 3 (2015): 297-313.

${ }_{10}$ Aidan Hehir, The Responsibility to Protect: Rhetoric, Reality and the Future of Humanitarian Intervention, (Basingstoke and New York: Palgrave Macmillan, 2012); Thomas G. Weiss, Military-Civilian Interactions: humanitarian crises and the responsibility to protect, 2nd ed, (Lanham: Rowman and Littlefield Publishers, 2005), 200-201.

${ }^{11}$ Philip Cunliffe, 'Sovereignty and the politics of responsibility', in Politics without Sovereignty: a critique of contemporary international relations, eds. Christopher J. Bickerton, Philip Cunliffe and Alexander Gourevitch (Oxon: University College London Press, 2007).

${ }^{12}$ Eli Stamnes, 'Speaking R2P' and the Prevention of Mass Atrocities', Global Responsibility to Protect, 1 no. 1 (2009): 70-89; Alex J. Bellamy, 'The Responsibility to Protect - Five Years On', Ethics and International Affairs, 24 no. 2 (2010): 143-169.
} 
that escalate to the point where humanitarian intervention is considered. The 'rallying cry' focuses on situations where mass atrocity crimes are occurring or foreseeable in the immediate future, and the idea that labelling a crisis an 'R2P situation' can help to elevate it above politics as usual to garner a quick and decisive response. It is important to recognise that these categories are not mutually exclusive, but rather reflect different aspects of the $\mathrm{R} 2 \mathrm{P}$ doctrine.

The R2P agreement outlines the requirement that the use of force has authorisation from the UN Security Council: as such the R2P agreement does not change international law. In cases where R2P is used as a rallying cry towards advocacy for humanitarian intervention the decision - per the R2P agreement - rests with the UN Security Council. The Council is a political body, requiring agreement from nine of its fifteen members and the agreement (or abstention) of all permanent members, but with few other formal restrictions on its decision-making. ${ }^{13}$ Legitimacy is central to the ability of the Security Council to wield power. ${ }^{14}$ As the debates over the Iraq war have demonstrated, credible evidence is intimately bound up with questions of legitimacy over decisions on the use of force. Though evidence is not a legal requirement for a UN Security Council decision (agreement between members is key) we suggest that any proposal for R2P intervention needs to give credible evidence and reasons that justify that course of action. ${ }^{15}$

\section{Analyzing the 2013 calls for Intervention}

We begin by outlining the response from the R2P community to the use of chemical weapons in Syria in August 2013, which were described as a 'game-changer' by some key R2P advocates. ${ }^{16}$ It is first useful to establish the political landscape in which this response took place. One of the most notable factors was the public statements of the Obama administration, which adopted a two-pronged strategy of simultaneously

\footnotetext{
${ }^{13}$ The UN Security Council is bound by the UN Charter (1945) and its Rules of Procedure which remain 'provisional'.

${ }^{14}$ Ian Hurd, After Anarchy: Legitimacy and Power in the United Nations Security Council, (Princeton: Princeton University Press, 2007).

${ }^{15}$ For discussion on this point, see Antonios Tzanakopoulos, 'Strengthening Security Council Accountability for Sanctions: The Role of International Responsibility', Journal of Conflict \& Security Law 19 no. 3 (2014): 409-426.

${ }^{16}$ Gareth Evans 'R2P down by not out after Libya and Syria', Open Democracy, 9 September, 2013; Weiss 'After Syria, Whither R2P?', E-International Relations, 2 February, 2014, 36. We use the term R2P advocates throughout in its broadest possible sense, recognizing of course the plurality of perspectives and approaches that inform R2P advocacy. For instance, in sharing our paper at conferences and other forums, one interlocutor was apt to point out that the Foreword to the 2011 ICISS Report detailed the main points of division between the twelve Commissioners. See ICISS, The Responsibility to Protect: The Report of the International Commission on Intervention and State Sovereignty, (Ottawa: International Development Research Centre, 2010)
} 
imposing a so-called 'red line' on the deployment of chemical weapons by the Syrian regime (formally issued by the President), as well as the incentive to pre-emptively disarm Syria's chemical weapons stockpile to avoid military repercussions (informally tabled by the foreign secretary). For instance, speaking at the Whitehouse on August 20 in 2012, Obama was resolute:

We have been very clear to the Assad regime, but also to other players on the ground, that a red line for us is we start seeing a whole bunch of chemical weapons moving around or being utilized. That would change my calculus. That would change my equation. [...] We have communicated in no uncertain terms with every player in the region that that's a red line for us and that there would be enormous consequences if we start seeing movement on the chemical weapons front or the use of chemical weapons. That would change my calculations significantly. ${ }^{17}$

While condemnation of any possible use of chemical weapons was to be expected, the response suggested by Obama would require evidence of who was ultimately responsible based on a verified, independent, expert assessment. As events transpired, Obama did not enforce the 'red line' despite the use of forceful strategic and humanitarian arguments. Indeed, a complex set of factors both domestically and internationally combined so that those ends came about by different means. For instance, despite the Cameron government's arguments for military intervention, the deliberations in the British parliament did not ultimately support that policy, in large part because of heavy reliance in the Joint Intelligence Committee briefing on "intelligence reports plus diplomatic and open sources". ${ }^{18}$ In other words, there was a gap that need closing between what was known (via robust evidence) and what was merely presumed. At the same time, the Obama administration remained unsure about both the appetite of the Congress to sanction any such military action (especially in light of Britain's stance), as well as the likely impact it would have on the Iran nuclear deal being negotiated at the time. Former secretary of defence Leon Panetta, for example, has subsequently told The Atlantic that he "didn't know it was coming". ${ }^{19}$

\footnotetext{
${ }^{17}$ Office of the Press Secretary, 'Remarks by the President to the White House Press Corps', White House, 20 August 2012, available at https://obamawhitehouse.archives.gov/the-press-office/2012/08/20/remarks-presidentwhite-house-press-corps

18 Jon Day, 'Syria: Reported Chemical Weapons Use - Letter from the Chairman of the Joint Intelligence Committee', Cabinet Office, 29 August 2013, 1.

19 Jeffrey Goldberg, 'The Day Obama Broke with the Washington War Hawks', The Atlantic, April 2016. http://www.theatlantic.com/video/index/473025/syria-red-line-that-wasnt/.
} 
The relevance of R2P to the conflict in Syria was clear long before August 2013. The UN's Independent International Commission of Inquiry on the Syrian Arab Republic documented concerns that violence in Syria since March 2011 may constitute crimes against humanity. ${ }^{20}$ From August 2012 the Commission added to its regular reports that it had reasonable evidence that war crimes had also been committed. ${ }^{21}$ The Commission even stated explicitly that "The Government has manifestly failed in its responsibility to protect its people", drawing on language on R2P from the World Summit outcome document. ${ }^{22}$ The perpetration of mass atrocity crimes is not a 'threshold criteria' for the applicability of the responsibility to protect - indeed the 2005 World Summit is clear that the scope of R2P includes the prevention of such crimes. However, since some commentary behaved as if evidence of the perpetration of mass atrocity crimes was a criterion - and such evidence is key to perceptions of legitimacy - it is worth recognising that the evidence of both crimes against humanity and war crimes was available long before August 2013. The scale of these crimes was such that a month prior to the chemical weapons attack the Commission reported that "[w]ar crimes and crimes against humanity have become a daily reality in the country". ${ }^{23}$ By August, more than 100,000 people had been killed in Syria since the conflict began. ${ }^{24}$

There was no doubt that the situation in Syria fit within the purview of R2P, including pillar three of R2P, with the Syrian government 'manifestly failing' to protect their population from war crimes and crimes against humanity. The R2P agreement is clear, however, that while coercive measures - including the use of force - can be used, it requires authorisation from the UN Security Council, in line with the UN Charter.

Despite this, media discussion on Syria shifted after the chemical weapons attacks, and became more likely to refer to the responsibility to protect. For example, in the

\footnotetext{
${ }^{20}$ United Nations, 'Report of the Independent International Commission of Inquiry on the Syrian Arab Republic', Human Rights Council, 23 November, 2011. A/HRC/S-17/2/Add.1: 20.

${ }^{21}$ United Nations, 'Report of the Independent International Commission of Inquiry on the Syrian Arab Republic', Human Rights Council, 16 August, 2012. A/HRC/21/50.

${ }^{22}$ Ibid: 1.

${ }^{23}$ United Nations, 'Report of the Independent International Commission of Inquiry on the Syrian Arab Republic', Human Rights Council, 18 July, 2013. A/HRC/23/58: 2.

24 'Syria Death Toll now above 100,000, says UN Chief Ban', BBC 25 July, 2013. Available at http://www.bbc.co.uk/news/world-middle-east-23455760.
} 
three months leading up to the attack on 21 August 2013 there were less than 100 news articles on Syria which referred to the responsibility to protect, yet in the three months after there were over 400 news articles which drew the connection. ${ }^{25}$ In fact, the year 2013 had more newspaper discussion on the connection between Syria and $\mathrm{R} 2 \mathrm{P}$ than any other year to date, with 1172 articles in total, half of which referred to chemical weapons. ${ }^{26}$ This shows a shift in media discussion of Syria in relation to $\mathrm{R} 2 \mathrm{P}$, beyond the specific statements made by R2P advocates.

In addition to the general media increase in discussions linking Syria and R2P, prominent $\mathrm{R} 2 \mathrm{P}$ advocates made the argument that military intervention could be an appropriate response provided the use of chemical weapons by the Syrian government could be proven. Lloyd Axworthy and Allan Rock made a strong argument that "R2P can and should be used as the basis for action in Syria" however this was caveated by their requirement that attribution of the Syrian government using chemical weapons be established first. ${ }^{27}$ After the chemical weapons attack Gareth Evans laid out a moral argument for taking military action against the Syrian government if indeed it had used chemical weapons. ${ }^{28}$ It is worth pointing out that these three figures are not merely commentators on R2P. Each played key roles in the creation and formalisation of R2P. Axworthy initiated the original Commission which developed the responsibility to protect in his former role as Canada's Foreign Affairs Minister; Rock was Canada's Ambassador to the United Nations during the 2005 World Summit negotiations; and Evans was Co-Chair of the original Commission. The important point here is that these significant R2P advocates saw the use of chemical weapons as a decisive event that made intervention a necessity so long as there was proof that the Syrian government was the perpetrator.

Of course, the attribution of the chemical weapons attack intersected with the political realities of the time. Prior to the chemical weapons attack there was little momentum for military intervention in Syria, whereas afterwards there was a period where

\footnotetext{
${ }^{25}$ A Factiva search of news articles with the search terms 'Syria' and 'responsibility to protect' between 21 May 2013 and 21 November 2013 returned 530 original articles. Of these, 96 were prior to the 21 August chemical weapons attacks and 434 were after. This search was limited to English language news sources.

${ }^{26}$ A Factiva search of news articles by year shows 1171 articles in 2013 that referred to both Syria and the responsibility to protect, with an average of 777 per year in the subsequent 2014-2016 period.

${ }^{27}$ Lloyd Axworth and Allan Rock, 'Looking Back at Kosovo can move the Syria Conflict Forward', The Globe and Mail, 26 August, 2013.

${ }^{28}$ Gareth Evans, 'R2P down but not out after Libya and Syria', Open Democracy, 9 September 2013. Available at https://www.opendemocracy.net/openglobalrights/gareth-evans/r2p-down-but-not-out-after-libya-and-syria.
} 
several states and regional actors pushed for the use of force. First, the UK, along with other regional actors opposed to the Assad government, was enthusiastic about a strong military response. ${ }^{29}$ The chemical weapons attack was positioned as casus belli for intervention. At the same time, the Obama Administration initially sought to avoid direct military engagement in another Middle East crisis and pushed back against reports of chemical weapons use, questioning attribution to forestall further involvement - before shifting towards intervention under political pressure from allies and domestic partisans. ${ }^{30}$ Meanwhile, states supportive of the Assad government notably Russia and Iran - questioned the origins of the chemical weapons attacks and identified the Islamic State as an alternative perpetrator, pointing to their alleged use of chemical weapons earlier in the conflict. These states were quick to dismiss the humanitarian dimension of the crisis and framed such claims as a convenient pretext for western intervention. ${ }^{31}$

The point here is that advocacy for R2P intervention arose in a broader geopolitical context that had the potential to influence information about the chemical weapons attacks. R2P advocates may have wanted proof that the Syrian government was the perpetrator, but the evidence of attribution available in the crisis moment, as the momentum for intervention gained pace, was potentially problematic. Moreover, these advocates faced strong incentives to take this information seriously, when the case for intervention made by states combined strategic arguments about deterrence and regional stability with humanitarian arguments that connected with the concerns of R2P. Indeed, as we indicated above, the language of R2P was already widely operative in media coverage and political commentary on the chemical weapons attack, often woven together with confident assertions that the Assad government was to blame for the attacks. ${ }^{32}$ The next section explores the way political dynamics can

\footnotetext{
${ }^{29}$ Geraint Alun Hughes, 'Syria and the Perils of Proxy Warfare, Small Wars \& Insurgency', 25, no. 3 (2014): 522438.

${ }^{30}$ Michelle Bentley, 'Syria and the Chemical Weapons Taboo: Exploiting the Forbidden', (Manchester: Manchester University Press, 2016); Bentley, 'Chemical Weapons Are Being Used in Iraq - but the US Won't Raise Hell about It', The Conversation, September 23, 2016. Available at https://theconversation.com/chemicalweapons-are-being- used-in-iraq-but-the-us-wont-raise-hell-about-it-65914. Even when the Obama Administration changed tack on intervention, they sought political cover and public sanction by putting the proposal before Congress, rather than relying on executive powers.

${ }^{31}$ Carroll Bogert, 'Syria's Chemical Weapons: The Russia Factor', Human Rights Watch, 26 September, 2013. Available at http://www.hrw.org/news/2013/09/26/syrias-chemical-weapons-russia-factor; Putin, 'A Plea for Caution from Russia', New York Times, 11 September, 2013.

${ }^{32}$ At the same time, there was a widespread assumption that independent attribution would confirm the Assad regime was behind the attacks. It is certainly the case that any R2P proposal for intervention in Syria was only, at this stage of the conflict, intended to protect Syrian civilians from the Syrian government.
} 
shape information provided by state intelligence agencies and the media, then contrast this with the technical process of independent attribution. In this context, we suggest $\mathrm{R} 2 \mathrm{P}$ advocates needed to take seriously the question of what counts as proof.

\section{Intelligence, Attribution and R2P Intervention}

Numerous sources feed into public perception of international crisis. While reporters 'on the ground' play an important role, by far the most common channel of information about an international crisis comes from governments. We focus on the special character of 'intelligence' the chief source of information emanating from states to illustrate the way national interest imperatives intersect with the representation of the crisis like the Syrian chemical weapons attack.

The starting point for any account of intelligence should be to note that it is geared towards future action and is in that sense concerned with risk management. Faced with an uncertain and often incoherent environment, including enemies that conceal their activities and intentions, and actively seek to mislead, intelligence analysts can only hope to produce 'estimates' or 'assessments' of likely futures, couched in wellrehearsed caveats about probability and inherent limitations. ${ }^{33}$ Following on from here, it is crucial to recognise that the subjects of intelligence estimates are determined by the risks they may pose to a specific set of interests. Thus, intelligence must be understood as 'a system of knowledge in the service of power'. ${ }^{34}$ It answers questions that are of concern to policy makers and political leaders, the end users of intelligence; the priorities and predispositions of users can influence the way these questions are answered, in terms of emphasis and priority; whatever intelligence is produced will be mobilised towards the user's strategic ends. ${ }^{35}$ In this sense, even impartial evidence and informed decision-making is thoroughly structured by national interest imperatives.

These structuring interests become much more explicit and influential around the justification of the use of force. As Bruce Berkowitz noted on the eve of Colin

\footnotetext{
${ }^{33}$ Richard K. Betts, Enemies of Intelligence: Knowledge and Power in American National Security, (New York: Columbia University Press, 2007); Mark M. Lowenthal, Intelligence: From Evidence to Policy, (Washington: CQ Press, 2006); Richard L. Russell, Sharpening Strategic Intelligence, (Cambridge: Cambridge University Press, 2007).

${ }^{34}$ James Der Derian, 'Anti-diplomacy, Intelligence Theory and Surveillance Practice', Intelligence and National Security, 8 no. 3 (1993): 35.

${ }^{35}$ Betts, Enemies of Intelligence: 66-103; Lowenthal Intelligence: 174-189.
} 
Powell's now notorious presentation to the United Nations on Iraqi weapons of mass destruction (WMD), intelligence is sometimes presented as fact - a 'slam dunk' or a 'smoking gun' - to strengthen the credibility of a political claim. ${ }^{36}$ Paul H. Barratt, former Secretary of the Australian Department of Defence, makes the same point regarding the Howard government's assertions about Iraqi WMDs:

The use of the phrase 'the Australian government knows' was a cardinal sin from the viewpoint of both Australian parliamentary procedure and professionalism in the treatment of intelligence. It admits of no doubt - this was not just an assessment, the best judgment we could make with the available evidence at the time, it was knowledge. We should not expect a subsequent inquiry to find that evidence was 'thin, ambiguous, and incomplete', which was the finding of the inquiry led by former DFAT Secretary Philip Flood. ${ }^{37}$

The point here is that because intelligence is always structured by the interest of its end users, there is real potential for it to be mobilised towards broader strategic ends in ways that misrepresent the underlying estimate. A similar perspective on the Iraqi WMD case is given by Richard K. Betts, an eminent scholar of intelligence theory and practice:

Although the bottom line analytic conclusion was wrong, in the absence of adequate collection it was the proper estimate to make from the intelligence available. No responsible analyst could have concluded in 2002 that Iraq did not have stocks of chemical and biological weapons concealed. The principle mistake was in the confident presentation of the analysis and the failure to make clear how weak the direct evidence was for reaching any conclusion and how much the conclusion depended on the logic of deduction from behaviour. $^{38}$

Of course, what Betts leaves out here is that intelligence agencies were placed under enormous pressure by Bush Administration policy makers to produce estimates in support of a certain policy ambitions. In this sense, there was a relationship between

\footnotetext{
${ }^{36}$ Bruce Berkowitz, 'The Big Difference Between Intelligence and Evidence', Washington Post, February 2, 2003.

${ }^{37}$ Paul H. Barratt, 'The Case for an Iraq War Inquiry Global Change', Global Change, Peace and Security, 26 no. 3(2014): 333.

${ }^{38}$ Betts, Enemies of Intelligence: 115.
} 
the strength of the estimates about Iraqi WMDs and the political context in which those assessments were made. More broadly, the leaked Downing Street Memo, minutes of a top level British Government meeting in July 2002, indicates: 'that the intelligence and facts were being fixed around the policy'. ${ }^{39}$ Put simply, the decision to change the Iraqi regime had already been made and WMDs, as well as ancillary humanitarian arguments, were merely convenient pretexts that could justify the policy to the American public and the international community. What this episode indicates is the potential for intelligence to be mobilised towards the strategic ends of states.

As we noted above, another common source of information about international crisis is media reportage. However, the chemical weapons issue should remind us of how unreliable the media has been around WMDs. ${ }^{40}$ For instance, in the lead up to the Iraq War in 2003, New York Times reporter Judith Miller published a series of articles asserting that Iraq had WMD and an ongoing active program to produce them. It turned out that much of this reporting was based in private briefings from a senior Bush Administration official who claimed that there was incontrovertible intelligence to that effect. ${ }^{41}$ More broadly, the recent Chilcot Report, the UK government's inquiry into the Iraq War, makes it clear that a comprehensive media strategy was an integral part of the push for war. ${ }^{42}$

To recap then: in the immediate wake of the Syrian chemical weapons incident the UK and Arab states asserted that the Assad regime was responsible. ${ }^{43}$ This claim was based in undisclosed intelligence, the authority of which was mobilised publicly in tandem with emotionally charged images of Syrians dead or dying from exposure to chemical agents. At the same time, the provenance of the chemical weapons attacks was muddied by competing claims made by other states, for instance, from Russia and Syria, as well as journalists, foreign affairs analyst, and the various non-state actors

\footnotetext{
${ }^{39}$ Mark Danner, 'The Secret Way to War', New York Review of Books 52 no 10 (2005).

${ }^{40}$ Perhaps the best acknowledgement of this fact is the mea culpa delivered by the New York Times about the failures of its pre-war coverage, which points to the way government officials exploited reporters to push the case for war. See The Editors, 'The Times and Iraq", New York Times, 26 May, 2004.

${ }^{41}$ Jack Shaffer, 'The Real Problem with Judith Miller', Politico, April 10, 2015.

42 The Chicot Report advances a broader critique of the case for war, which is scathing in its assessment of the way intelligence was used by government. See 'The Report of the Iraq War Inquiry', Report of the Privy Council, 2016. Available at http://webarchive.nationalarchives.gov.uk/20171123122743/http://www.iraqinquiry.org.uk/thereport/.

${ }_{43}$ N.A.J. Taylor, 'Responsibly protecting Syrians', Iraq War Inquiry Group, May 13, 2013. Available at http://iraqwarinquiry.blogspot.com.au/2013/08/responsibly-protecting-syrians.html on August 2013. As we noted above, the US was more reticent about attribution initially, a position that aligned with its strategic framework of non-intervention.
} 
on the Syrian battlefield. ${ }^{44} \mathrm{R} 2 \mathrm{P}$ advocates making the case for intervention were put in a position where the information immediately available was provided by selfinterested states and a potentially briefed media, both with a recent history of unreliability around WMD.

By contrast, the sort of robust independent evidence that would ideally have formed the basis for determining responsibility for the chemical weapons attacks was unavailable. This is largely because chemical weapons experts establish attribution through rigorous, transparent and verifiable methodologies focused on the assessment of technical information about the chemical agent and the delivery system in question. There are technical, practical, legal and political hurdles that can constrain a swift outcome. In the context of the Syrian chemical weapons attacks, technical constraints on UN inspections include not only the procurement of evidence, witness accounts and testimony (from medics, for example), but also the limitations of an interagency process that requires testing in multiple facilities over the course of several days. ${ }^{45}$ Practical constraints include the inescapable problem that Syria is an active war zone, and UN inspectors must prioritise both their own personal safety, as well as their mission's integrity. For instance, the proper handling of evidence and selection of witnesses is a difficult task during any conflict, whether the relevant parties comply or not. No one outside of the select few negotiators, likely not even the UN inspectors themselves, could have been aware what evidence had been supplied by the Syrian Government, opposition force, or external actors such as Russia, Iran, Saudi Arabia, Turkey, France, UK, US, and Israel.

On the politico-legal front, the Assad government's obligations were also complex and not altogether as rigid as commonly supposed. Syria was not then a state-party to the international convention banning the use of chemical weapons, though it is party to the 1925 Geneva Convention. Assad was under no legal obligation to facilitate inspections of Syria's sovereign territory, despite assertions to the contrary based on customary international law. ${ }^{46}$ In fact, it was Assad who agreed to the inspections by United Nations Mission to Investigate Allegations of the Use of Chemical Weapons

\footnotetext{
${ }^{44}$ Tim Aistrope, Conspiracy Theory and American Foreign Policy, (Manchester: Manchester University Press, 2016): 96-97.

${ }^{45}$ J.P. Zanders, 'Syria: Should the UN Investigators Pass Judgement?', The Trench, 23 August, 2013. Available at http://www.the-trench.org/syria-should-un-investigators-pass-judgement/.
}

\footnotetext{
46 Tim Dunne, 'Syria and the Laws of War: Permission Accomplished?’ The Interpreter, 27 August 2013.
} 
in the Syrian Arab Republic, which had begun to collect evidence about the use of chemical weapons in Syria only a day before the attack. ${ }^{47}$ Both the World Health Organization (WHO) and Organization for the Prohibition of Chemical Weapons (OPCW) offered assistance to components of the UN mission led by Professor Åke Sellström. For instance, the mandated UN Sellström investigation reported in December 2013 with the narrow conclusion that 'chemical weapons had been used' including against civilians - on five occasions between March and August 2013, without any attempt to attribute those attacks to any one party to the conflict. ${ }^{48}$ It had, however, investigated only seven of sixteen alleged attacks beginning as early as October 2012. Simply put, independent verification of evidence that could attribute any alleged use to any one party to the conflict would be technically and politically difficult to establish, and at any rate was never included in the mandate of any subsequent mission by the OPCW-UN or OPCW. ${ }^{49}$

The point here is that independent reliable evidence on attribution - which R2P advocates might have relied upon instead of state intelligence - was not available and, by its very nature, could not have been. Moreover, states publicly attributing the use of chemical weapons to the Syrian government were unwilling or unable to disclose the technical information that would have allowed independent experts to confirm their attribution. According to an advisory opinion from noted chemical weapons specialist J. Perry Robinson:

Whether the many allegations of Syrian poison-gas warfare are or are not true cannot reasonably be judged on the evidence currently in the public domain... [Furthermore] the several governments which have explicitly accused the Syrian regime of using Sarin nerve-gas against the rebels seem to be withholding evidence that, if disclosed, might make their charges more believable than they are. The gap in disclosure is not so much intelligence from sensitive sources or methodologies but is instead straightforward

\footnotetext{
${ }^{47}$ Indeed, the team was staying in a hotel just twelve kilometres from the incident site.

${ }^{48}$ United Nations Mission to Investigate Allegations of the Use of Chemical Weapons in the Syrian Arab Republic, Report of the Alleged Use of Chemical Weapons in the Ghouta Area of Damascus on 21 August 2013, Report A/68/663, December 13, 2013, p.2.

49 The reports of the OPCW-UN mission which ceased in September 2014 are collated here: https://opcw.unmissions.org/other-relevant-documents and https://opcw.unmissions.org/opcw-un-reports. Whilst the reports of the subsequent OPCW mission are located here: https://www.opcw.org/special-sections/syria/factfinding-mission-reports/
} 
description for scientific audiences of the procedures that have been used for analysing physiological and environmental samples. ${ }^{50}$

As it turned out, the public case for military intervention made by the UK and US governments did not ultimately withstand high levels of community cynicism about deceptive intelligence around WMDs and Middle-Eastern wars.

Nevertheless, what all this highlights is the danger faced by R2P advocates making a case for intervention in a crisis. In the absence of timely independent attribution there is potential for assumptions based in state intelligence or potentially unreliable media to be acted on. In such an environment, the reticence and scepticism of expert communities is liable to be drowned out by the political momentum and the demand for action. As one chemical weapons specialist, J.P. Zanders sees it:

Instant judgement does not equal instant justice. It merely satisfies other hidden desires: the dark gratification of being able to Saddam-ise yet another political leader, the clamouring for policy objectives that have little to do with the chemical attacks as such, the uncontrollable eagerness to impart wisdom... the need to simplify complex realities for a tweeting global audience.... ${ }^{51}$

The point here is that the chemical weapons attacks in Syria indicate a problematic dynamic. On the one hand, the sort of robust independent evidence that would ideally form the basis of an R2P case for military intervention is often unavailable when there is political momentum for action - or indeed when the prospect of further civilian casualties seems imminent. On the other hand, the information that is available (which inevitably informs the political momentum for action) is routinely produced by state intelligence services - or a briefed media - and shaped by the interests and priorities of its end users. Although many R2P advocates supported military intervention in Syria on the proviso that responsibility for the chemical weapons attacks be proven, independent verification was in reality never a possibility. Put simply, they could not have reasonably known who committed this heinous act.

This section has explored the implication of crisis dynamics that confront R2P advocates. We have established that intelligence, a key source of information

\footnotetext{
${ }^{50}$ Julian Perry Robinson, 2013. 'Alleged Chemical Weapons Use in Syria', Occasional Paper Series: Harvard Sussex Program 4 (2013): 3.

${ }^{51}$ Zanders, 'Syria: Should the UN Investigators Pass Judgement?'.
} 
emanating from states, is implicitly (and on some notable occasions, explicitly) shaped by national interest, including the policy goals of its end users. We have suggested that this information is often the most readily available in crisis situations, especially when independent verification can involve complicated and time consuming processes. In the final section we explore the potential consequences of this dynamic and offer a word of caution for R2P advocacy around military intervention.

\section{R2P Advocacy and the Perception of Pretexts}

One way to explore the risks associated with unreliable information is situate the different concerns of $\mathrm{R} 2 \mathrm{P}$ in relation to the dynamics of sovereignty in crisis circumstances. As we noted earlier, for our purposes the concerns of R2P can be usefully delineated under the headings 'rallying cry' and 'policy agenda'. The former is about 'speaking R2P', which is to say describing a situation as R2P to elevate it within political debates; the later refers to implementing and mainstreaming the prevention strategies of $\mathrm{R} 2 \mathrm{P}$ throughout domestic, regional and international infrastructure, which may be done with or without describing it as R2P. ${ }^{52}$ It is important to reiterate that these categories are not mutually exclusive, but rather reflect different aspects of the R2P doctrine. Of particular interest here is Bellamy's argument that the rallying cry advocacy for R2P based military intervention has shown limited effectiveness in changing the underlying political dynamic driving international responses to a crisis. ${ }^{53}$ It follows that rallying cry advocacy may only be effective when the underlying political dynamic are aligned with intervention. Thus, even when states appear to embrace humanitarian arguments for intervention, there is a significant risk that their justification and the information that supports it will be rooted in strategic imperatives.

Relating this situation to the dynamics of sovereignty in crisis circumstances can highlight the danger for R2P advocates. Two accounts of sovereignty are relevant: de

\footnotetext{
52 Stamnes, 'Speaking R2P'; Bellamy, 'The Responsibility to Protect - five years on'. It has been argued elsewhere that the framing of 'rallying cry' and 'policy agenda' is overly simplistic, as R2P can serve as a 'catalyst for debate' that helps to foreground protection needs, but does not determine a specific course of action (which will depend on multiple normative, strategic and pragmatic factors) Jennifer Welsh, 'Norm Contestation and the Responsibility to Protect', Global Responsibility to Protect, 5 no. 4 (2013): 365-396. We use the distinction here however, as there was an attempt by advocates to link R2P and chemical weapons use in this case as part of a call to action, in line with the 'rallying cry' framing.

${ }^{53}$ Bellamy, 'The Responsibility to Protect - five years on'.
} 
jure sovereignty, most familiar to internationalists and cosmopolitans, points to the norms, practices and social relations that have given meaning to sovereignty over time; de facto Sovereignty, most familiar to classical realists and critical legal scholars, points to the ultimate authority that allows the sovereign to identify a crisis and act decisively to resolve it, and to make rules but not be bound by them, particularly in exceptional circumstances. ${ }^{54}$ According to Moses;

[...] while de jure theories of sovereignty find meaning for the term in shared understanding, practices, legitimacy and recognition, de facto theories find sovereignty in the opposite: at points of crisis, misunderstanding, lack of recognition, and, most importantly, in the forceful resolution of these intense political conflicts. ${ }^{55}$

Of course, these two accounts are not mutually exclusive: they describe the normative quality and hierarchical character of sovereignty. While sovereignty emerges and is reproduced in social contexts that shape identity and possibilities for action, the ultimate authority of the sovereign in that social context means that norms and regularities that might bind some actors are much more contestable at the apex of political power. At the same time, we can point to the way influential assemblages of norms, practices, rules and historical structures shape, constrain and enable the exercise of sovereign power in palpable ways.

On the above delineation, we can associate $\mathrm{R} 2 \mathrm{P}$ with de jure sovereignty, to the extent that it seeks to impact the legal and normative dimensions of sovereignty. Conversely, we can associate military intervention with de facto sovereignty, to the extent that it is only ever at the point of crisis and the 'forceful resolution of intense political conflicts' that intervention takes place. Understood this way, the vulnerability of rallying cry advocacy is plain. In the crisis moment where the use of force is imminent, when de facto sovereignty is most likely to be enlivened, R2P advocates seek to mobilise the de jure norm of sovereign responsibility. Thus, advocacy for R2P based intervention will often coincide with the powerful assertion

\footnotetext{
${ }^{54}$ Jeremy Moses, 'Sovereignty as Irresponsibility: A Realist Critique of the Responsibility to Protect', Review of International Studies, 39 n. 1 (2013): 113-135.

${ }^{55}$ Ibid, 22-23
} 
of sovereign interest. R2P advocates must therefore be especially careful to insulate against the perception and possibility of de facto sovereign power working through international law and humanitarian pretexts.

While understandable in the face of the 'extreme', we suggest that the mobilisation of political momentum by R2P advocates - particularly where independent attribution of mass atrocity crimes is unavailable - will entail two significant dangers. First, it will risk undermining the integrity of the $\mathrm{R} 2 \mathrm{P}$ intervention. Toni Erskine has recently emphasised the moral imperative of informed decision-making around R2P interventions. Erskine makes this point as part of a broader engagement with the concept of 'resultant moral luck' - the idea that moral judgement about past events can inadvertently include in the consideration aspects of chance that were beyond the control of any specific actor. ${ }^{56}$ The primary implication of this concept relates to judgments about moral responsibility. However, Erskine extends the analysis to show how it also imposes strong prospective prudential obligations on moral agents when they make decisions about future actions:

This variation on resultant luck speaks to considerations of prospective moral responsibility by reinforcing the imperative to act only when it is possible to offer a fully informed, compelling justification of the decision to do so, which heeds clear precautionary principles and will withstand any result. It also warns of the folly in allowing the morality of a decision to be either held hostage to - or redeemed by - fortune. ${ }^{57}$

This analysis suggests there are risks in proceeding with an R2P intervention before there is robust independent evidence to support that course of action.

Second, R2P advocates would also risk amplifying the perception that states sometimes exploit humanitarian crisis in pursuit of strategic ends. As Mallavarapu highlights, colonial legacies already leave some states suspicious of the power imbalances involved in military intervention for humanitarian purposes, especially when former colonial powers - who historically justified their initial conquest in

\footnotetext{
${ }^{56}$ Toni Erskine, 'Moral Responsibility - and Luck? - in International Relations', in Chris Brown and Robyn Eckersley, The Oxford Handbook of International Theory, (Oxford: Oxford University Press, 2018).

${ }^{57}$ Ibid, 10.
} 
moral terms — often lead interventions in their former colonies. ${ }^{58}$ Bellamy has contested these neo-imperial arguments on the grounds that they deny the consistent support for R2P from many states in the Global South. ${ }^{59}$ It is certainly the case that African states have shown leadership on R2P as Article 4(h) of the 2000 Constitutive Act of the African Union includes the right to intervene in cases of war crimes, genocide and crimes against humanity, predating the 2005 World Summit agreement. Whatever the case, the R2P community must be on guard against advocacy that risks undermining the purported impartiality of the R2P doctrine and inviting the perception that states manipulate humanitarian crisis as pretexts in the pursuit of other policies.

This perception and possibility may be to some extent unavoidable, but that does not overwhelm R2P as a positive project. Instead, both the risks highlighted above suggest that values of caution and impartiality must underpin any rallying cry advocacy for R2P based intervention. At the same time, it is worth emphasising that the policy agenda aspects of R2P comprise the greater part of the R2P project and remain the most promising avenue for tangible political change. Raising awareness, building early warning systems, and developing regional and international networks for preventative diplomacy, can make very significant contributions towards preventing mass atrocity crimes. Our analysis of the discourse surrounding the Syrian chemical weapons crisis of 2013 indicates that if the legitimacy of R2P based intervention (and R2P more broadly) is to be maintained there must first - and principally — be reliable and verified evidence.

\section{Conclusion: Robust evidence as a precondition for R2P legitimacy}

This article set out to explore the tension between the normative and political content of R2P. We did so by examining the discourse that surrounded the Syrian chemical

\footnotetext{
${ }^{58}$ Siddharth Mallavarapu, 'Colonialism and the Responsibility to Protect', in Ramesh Thakur and William Maley (eds) Theorising the Responsibility to Protect, (Cambridge: Cambridge University Press, 2015). There is a related literature on the role of non-Western and non-liberal emerging powers in R2P advocacy, see Ramesh Thakur, 'R2P after Libya and Syria: Engaging Emerging Powers', The Washington Quarterly 36 no. 2 (2013): 61-76; Hardeep Singh Puri, Perilous Interventions: The Security Council and the Politics of Chaos, (New York: Harper Collins, 2016); Oliver Stuenkel, 'Post-Western World: How Emerging Powers Are Remaking Global Order', Foreign Affairs, 13 February, 2017. One reviewer pointed out the irony that many of these interventions-in Abysinia, Mesapotamia, Manchuria, and Rhodesia, for example - involved chemical weapons in one way or another.

${ }^{59}$ Alex J. Bellamy, The Responsibility to Protect: A Defence, (Oxford: Oxford University Press, 2015), 112-120.
} 
weapons attacks of 2013, where humanitarian and security imperatives were drawn together around the use of chemical weapons, historical experience with WMDs introduced a level of suspicion concerning politicisation, and the attribution of the attack was contested in ways that reflected the geopolitical structure of the Syrian conflict. We have argued that R2P advocates can be confronted by crisis dynamics where the political momentum for military intervention runs ahead of independent and verification of $\mathrm{R} 2 \mathrm{P}$ violations. We contrasted the character of intelligence and media reportage with the technical process of independent attribution and demonstrated that the sort of evidence that would ideally legitimize an R2P intervention was unavailable when there was political momentum for action. Conversely, the information that was available was largely produced by state intelligence organisations - or a briefed media - and shaped by the interests and priorities of its end users. In this context, we suggested that the mobilisation of political momentum by R2P advocates entails significant dangers: first, it risks undermining integrity of R2P if evidence is later discredited; and, second, it risks amplifying the perception and potential reality that states sometimes exploit humanitarian pretexts in pursuit of other strategic ends.

At a minimum, any case for R2P based intervention, whether it is advanced by R2P advocates or states in the context of a UN resolution, needs to be based in robust, impartial and publicly verifiable evidence. We have suggested that on the issue WMD this requires the application of a rigorous and independent attribution process that would not necessarily keep pace with an unfolding crisis or the currents of politics. What is particularly striking in the case we examined is the extent to which the expert community best positioned to contribute to the attribution process was largely sidelined from the political discourse. The sort of robust and impartial case that we argue is a necessity would need to be based not only in a dialogue between expert communities about the facts at hand and the realities of the attribution process, but also in the public availability of basic technical data that could be analysed by multiple independent experts. 